\title{
APPROACHES TO THE INTERPRETATION OF THE TERM “HISTORICAL FINANCIAL INFORMATION" AS THE CRITERION FOR THE CLASSIFICATION OF AUDIT, REVIEW, AND OTHER ASSURANCE ENGAGEMENTS
}

\author{
Nataliia Shalimova', Iryna Androshchuk ${ }^{2}$ \\ Central Ukrainian National Technical University, Ukraine
}

\begin{abstract}
The criterion "underlying subject matter" and the associated criterion "subject matter information" is an essential element of the assurance engagements and the basis for distinguishing their different types. The purpose of the study is to define the characteristics of "historical financial information" and the forms of its structured representation as a defining criterion for the classification and differentiation of audit, review, and other assurance engagements. The subject of the study is the term "historical financial information" in the context of its use in International Standards on Quality Control, Auditing, Review Engagements, Assurance Engagements, and Related Services. Methodology. To achieve the goal set in the work, a complex of general scientific methods (analysis, synthesis, induction, deduction, abstraction) and methodical techniques (systematization, generalization, review, comparison) was used. In the study of the historical stages of using the terms "financial statements" and "historical financial information", the method of system analysis, historical and logical methods were used. The study of their essence as mandatory elements of the assurance engagements was based on provisions of the dialectical method of knowledge of processes and phenomena in their interconnection and development. In developing approaches to the interpretation of the term "historical financial information", the algorithm for selecting engagements for different types of objects and directions of standardization a method of modelling was applied. Results. Based on the systematization of the historical stages of the use of terms "financial statements" and "historical financial information" in IAASB International Standards, it is substantiated that the interpretation of the term "historical financial information" is not specific, allows the ambiguity of interpretations, which complicates the processes of identifying the type of engagements, agreeing its conditions, lead to dissatisfaction of users with the results of auditors' work. It is substantiated that prior to the definition of the term "historical financial information" as the main criterion for distinguishing between audit, review, and other assurance engagements, two approaches can be applied: narrow when the term "historical financial information" is limited to a complete set of financial statements, a separate financial statement, an account, an article or item of financial statements, and a broad one, which stipulates the allocation of different forms of structured presentation on the basis of specification of required characteristics of historical financial information. Problems of their influence on the application of International Standards are generalized. Practical implications. Based on the proposed approaches, an algorithm for selecting objects that can be the subject of various assurance engagements has been elaborated. It is useful for both auditors and for responsible parties, intended user, clients and will increase the effectiveness of their cooperation and reduce the "expectations gap". Problems of the impact of "narrow" and "broad" approaches to the interpretation of the essence of the term "historical financial information" on the content and directions of the improvement of International Standards and national regulatory documents are systematized. Value/originality. The research developed a theoretical approach to distinguishing types of audit services based on the specification of the scope of the application of International Auditing Standards (ISAs) and Assurance Engagements (ISAEs). There is substantiated the possibility of using narrow and broad approaches to understanding the term "historical financial information" as a subject matter, the definition of possible forms of structured representation of historical financial information as a subject matter information and the key condition for the delineation of audit, review, and other assurance engagements.
\end{abstract}

Key words: assurance engagements, audit engagements, historical financial information, financial statements.

JEL Classification: M40, M42

Corresponding author:

${ }^{1}$ Department of Audit and Taxation, Central Ukrainian National Technical University.

E-mail: nataliia.shalimova@gmail.com

${ }^{2}$ Department of Audit and Taxation, Central Ukrainian National Technical University.

E-mail: GM_GM@ukr.net 


\section{Introduction}

Although financial statements are traditionally considered to be the main object of audit and this viewpoint has traditionally been formed and remains in the theory and practice of auditing, the broader understanding of the essence of the audit led to the widespread definition of the audit since the 90s of the twentieth century. Gradually it was replaced by the term "assurance engagement" and the structure of audit services has changed significantly, which is characterized by the following:

1. International Framework for Assurance Engagements and International Standards on Quality Control, Auditing, Review Engagements, Assurance Engagements, and Related Services (ISAs, ISREs, ISAEs, ISRSs) were developed. They are applied to different by its content engagements (audit of historical financial information; review of historical financial information; assurance engagements other than audits or review of historical financial information; related services).

2. The content of other documentation in the sphere of auditing was enhanced, particularly Codes of Ethics for Professional Accountants, in order to make detailed requirements for different types of auditing services.

On the one hand, these tendencies are logical and predictable since the information-oriented society demands from auditors to expand the range of services and to include any information, but on the other hand, the tendencies are not easy to perceive and change the traditional idea of the content and purpose of the audit. As Higson A. states in Corporate Financial Reporting (2014, p. 111), "The refocusing of auditors on assurance services could almost be classified as an audit revolution."

For that reason, organizational and methodological principles of identification, acceptance, and fulfilment of various types of assurance engagements as the main components of the auditing services need constant improvement, taking into account the tendencies of a complication of their structure and the necessity to comply with the requirements of the International Standards. But for further development of the theory and practice, there should be a clear classification of assurance engagements, features of separating the audit and reviewing historical financial information from assurance engagements other than audit or review of historical financial information.

Despite the fact that basic elements of the assurance ((a) a three-party relationship involving a practitioner, a responsible party, and intended users; (b) an appropriate underlying subject matter; (c) suitable criteria; (d) sufficientappropriate evidence; and (e) a written assurance report in the form appropriate to a reasonable assurance engagement or a limited assurance engagement), which are the basis for such a classification, find their reflection in the International Standards and the International Conceptual Framework for Assurance Engagements (Article 26), their interpretation is not concise. It has the ambiguity of interpretations, which complicates the work of auditors in the process of identifying the type of engagement, harmonizing the conditions of the engagement, impeding its proper implementation, and resulting in dissatisfaction of users with the results of the work of auditors, narrowing the market of audit services, not using the audit potential to the full.

\section{A literature review of audit and assurance classification}

It should be noted that the study of this issue has a slightly different dimension in foreign and national publications.

The publications of the Ukrainian scholars have still been inclined to the classification of audit services, which is a consequence of the "broad" interpretation of the audit and was used in foreign publications of the twentieth century that were translated into the Russian and Ukrainian languages in the early 1990s, for example, the textbook "Montgomery's Auditing" (1997, pp. 38-41) and the textbook by Arens A.A. \& Loebbecke J. (1995, pp. 11-12). This classification included auditing of financial statements, compliance audits and operational audit (management, efficiency, etc.), and the features of such a classification were the object of the audit, target direction, direction, scope of coverage, assignment, etc.

These classifications are certainly important but the starting point for the classification of audit services should be International Standards, taking into account their crucial role in the regulation and standardization of auditing, as well as the need to comply with the requirements of these documents in the process of auditing.

However, the national science has rather fragmentary studies. In particular, the study of the main types of audit services and their comparison according to the criteria that are formed with the use of obligatory elements is suggested by Davydov H. (2009, pp. 81-84, 104-113) and Gedz M. (2007, pp. 79-80). These classifications are an attempt to delineate the engagements. But the first textbook does not specify the nature of the subject of the engagement and the second one does not take into account the possibility of financial information to have a predictive and historical (past time) character. Also, national scientists suggest classification of audit services using required elements of an assurance engagement for specific objects. Samchynska Ya. (2012, p. 98) made an attempt to specify the type of audit services for such an object as the strategic principles of the company's operation; Proskurina N. (2014) studied observance of the principle of continuity of activities. There are also suggestions of options for introducing an audit of taxation (tax audit) and methods for checking the indicators of tax returns into the current regulatory base of an audit by Malyshkin O. (2015, p. 211), Petryk O. (2012, p. 13), Artyukh O. (2015). 
This problem is encountered by scientists and experts of other post-Soviet countries, and it is particularly acute in those countries that have gone through the introduction of their own audit standards that are not consistent with the requirements of International Standards. In particular, S. Pankova (2013) focuses on the problem of identifying such types of audit services as verification of project (forecast) investment documentation, an audit of marketing and, in general, problems of classification of audit services (International Federation of Accountants (IFAC/IAASB), 2012).

In foreign studies, a considerable attention is paid to the analysis of the evolution of audit in the context of engagements of an audit of financial statements (Ittonen K., 2010). The textbooks provide a classification of assurance engagements that meets the requirements of International Standards (Soltani B., 2007; Eilifsen A., Messier Jr., W.F., Glover S. \& Prawitt D., 2006; Gill G., Cosserat G., Leung P. \& Coram P., 2001). But it should be noted that there is also a reference to the traditional classification of the audit, which is not consistent with International Standards (Drd. Pop (Grigorescu) I.I., 2012). In the context of other assurance engagements, they are presented in the study of specific objects (Hasan M., Maijoor S., Mock T.J., Roebuck P., Simnett R. \& Vanstraelen A., 2005; Simnett R., Nugent M. \& Huggins A.L., 2009; Janković S. \& Krivačić D., 2014; Sonnerfeld A., 2014).

In the context of these issues, it is advisable to draw attention to the developments of other countries and international organizations. The International Standards focused on differences between reasonable assurance engagements and limited assurance engagements that were considered by such features as (1) objective, (2) evidencegathering procedure, (3) the assurance report (since the standards published in 2004). In particular, the Federation of European Accountants has been offered Survey on the Provision of Alternative Assurance and Related Services across Europe, which analyses the differences between different services. In November 2015, the Australian government (the Department of Finance) issued guidance on the delimitation of the concepts of "audit" and "assurance" (Resource Management Guide No. 210 Clarification of the Terms "Audit" and "Assurance"), the purpose of which was to provide detailed recommendations for users about the elements. They provide the analysis of various situations and issues arising from the use of the terms "audit" and "assurance" and suggestions on how to avoid them.

\section{Problems of classification of assurance engagements}

The abovementioned works characterize differences among the types of assurance engagements at the stage of their adoption, as well as at the stages of their implementation and completion. But the most important are the criteria that make it possible to clearly distinguish the audit and the review of historical financial information from other assurance engagements. These differences are due, first of all, to the characteristics and required elements of the assurance engagement.

The first three elements (three-party relations, subject, and criteria) determine the possibility and conditions for accepting the assurance engagement, and also in some way affect the outcome of the engagement; the fourth and fifth elements (evidence and report) directly affect the process and determine the outcome of this engagement. However, the very criterion "subject" and the associated criterion "subject matter information" are the basis for the identification of various types of assurance engagements and, therefore, the question arises to specify the content of the term "historical financial information", which remains unnoticed in scientific works.

The purpose of the study is to define the characteristics of "historical financial information" and the forms of its structured representation as a defining criterion for the classification of engagements for audit, review, and other assurance engagements.

\section{Methodology}

The research was done on the basis of the theory of scientific cognition using a systematic approach to the study of phenomena and processes. To achieve the goal set in the work, a complex of general scientific methods (analysis, synthesis, induction, deduction, abstraction) and methodical techniques (systematization, generalization, review, comparison) was used. The information base of the study has become the official documents and standards of the International Auditing and Assurance Standards Board of the International Federation of Accountants, educational, scientific, monographic, and reference literature, scientific publications of the national and foreign scientists on the theory and methodology of auditing and assurance.

In the study of the historical stages of using the terms "financial statements" and "historical financial information", the method of system analysis, historical and logical methods were used. The study of their essence as mandatory elements of the assurance engagements was based on the provisions of the dialectical method of knowledge of processes and phenomena in their interconnection and development. In developing approaches to the interpretation of the term "historical financial information", the algorithm for selecting engagements for different types of objects and directions of standardization a method of modelling was applied.

\section{Study of the interpretation of the subject matter and subject matter information in the International Standards}

The historical stages of the development of International Standards and the use of terms "financial statements" and "historical financial information" in the context of determining the scope of International Standards can be summarized as follows (Table 1). 
Table 1

\section{Historical stages of using the terms "financial statements" and "historical financial information"} in International Standards

\begin{tabular}{|c|c|}
\hline Stage and Characteristics & Distinctive Features \\
\hline $\begin{array}{l}\text { Stage 1. 1999-2001 } \\
\text { The origin and development of } \\
\text { International Standards on Auditing (ISA) } \\
\text { (International Standards on Auditing \& } \\
\text { IFAC Code of Ethics. 1999; } 2001 \\
\text { IFAC Handbook of Auditing and Ethic } \\
\text { Pronouncement). }\end{array}$ & $\begin{array}{l}\text { 1. In the foreword, it is noted that ISAs are intended for the use in the audit of financial } \\
\text { statements, but if they are adapted, they may be applied to the audit of other information; } \\
\text { 2. The conceptual framework of International Standards on Auditing (ISA 120) operates the } \\
\text { term "financial statements". } \\
\text { 3. The glossary of terms interprets Financial Statements as "the balance sheets, income } \\
\text { statements or profit and loss accounts, statements of changes in financial position (which may } \\
\text { be presented in a variety of ways, for example, as a statement of cash flows or a statement of } \\
\text { fund flows), notes and other statements and explanatory material, which are identified as being } \\
\text { a part of the financial statements." }\end{array}$ \\
\hline $\begin{array}{l}\text { Stage 2. } 2003 \\
\text { Further development of ISA and adoption } \\
\text { of International Standards on Assurance } \\
\text { Engagements } 100 \\
\text { Handbook of International Auditing, } \\
\text { Assurance, and Ethic Pronouncement. } \\
2003 \text { Edition }\end{array}$ & $\begin{array}{l}\text { 1. The term "historical financial information" was introduced but it was suggested only in the } \\
\text { Foreword where it was stated that International Standards on Auditing (ISA) were issued as the } \\
\text { standards to be applied in reporting on the credibility of historical financial information," and } \\
\text { in certain standards, particularly ISA } 545 \text { "Auditing Fair Value Measurements and Disclosures", } \\
810 \text { "The Examination of Prospective Financial Information." } \\
\text { 2. There was no clear interpretation of the term "historical financial information". } \\
\text { 3. The text of International Standards applies the term "financial statements", the interpretation } \\
\text { of which was not changed. }\end{array}$ \\
\hline $\begin{array}{l}\text { Stage } 3.2004 \\
\text { Acceptance of the International } \\
\text { Framework for Assurance Engagements } \\
\text { and the introduction of a clear structure } \\
\text { of standards, review of ISA } \\
\text { (Handbook of International Auditing, } \\
\text { Assurance, and Ethic Pronouncement. } \\
2004 \text { Edition). }\end{array}$ & $\begin{array}{l}\text { 1. The term "historical financial information" is again suggested only in the Foreword while } \\
\text { defining the scope of the ISA, and in some standards (ISAs } 545 \text { and } 810) \text {. } \\
\text { 2. The blocks of standards "Audits and Review of Historical Financial Information" and } \\
\text { "Assurance Engagements other than Audits or Reviews of Historical Financial Information" } \\
\text { were introduced. } \\
\text { 3. Interpretation of the term "financial statements" was not changed and is further used in } \\
\text { International Standards on Auditing. }\end{array}$ \\
\hline $\begin{array}{l}\text { Stage 4. } 2005-2009 \\
\text { Review of ISA, the introduction of new } \\
\text { standards and development of the projects } \\
\text { of the new International Standards } \\
\text { on Assurance Engagements other than } \\
\text { Audits or review of Historical Financial } \\
\text { Information } \\
\text { (Handbook of International Auditing, } \\
\text { Assurance, and Ethic Pronouncement. } \\
\text { 2005-2007 Edition). }\end{array}$ & $\begin{array}{l}\text { 1. The interpretation of the term "financial statements" was changed to "a structured } \\
\text { representation of the historical financial information." } \\
\text { 2. The term "historical financial information" is again suggested only in the Preface when } \\
\text { defining the scope of the ISA, and in some standards (ISA } 545 \text { and } 810 \text { ). But this term is widely } \\
\text { used in the new standards, particularly on quality control: International Standards on Quality } \\
\text { Control (ISQCs 1) "Quality Control for Firms that Perform Audits and Reviews of Historical } \\
\text { Financial Information, and Other Assurance and Related Services Engagements" and ISA } 220 \\
\text { "Quality Control for Audits of Historical Financial Information". }\end{array}$ \\
\hline $\begin{array}{l}\text { Stage 5. 2010-2017 } \\
\text { Review of ISA, the introduction of new } \\
\text { standards, review of the International } \\
\text { Framework for Assurance Engagements } \\
\text { (Handbook of International Quality } \\
\text { Control, Auditing, Review, Other Assurance, } \\
\text { and Related Services Pronouncements. } \\
\text { 2010, 2012, 2013, 2014, 2015, 2016-2017 } \\
\text { Edition). }\end{array}$ & $\begin{array}{l}\text { 1. The term "historical financial information" was introduced into the Glossary of Terms. } \\
\text { 2. The term "historical financial information" is used in the Foreword to determine the scope } \\
\text { of the application of International Standards on Auditing and International Standards for } \\
\text { Engagements for Review. } \\
\text { 3. It was first mentioned that ISAs are written in the context of an audit of financial statements } \\
\text { by an independent auditor and they are to be adapted as necessary in the circumstances when } \\
\text { applied to audits of other historical financial information. } \\
\text { 4. The interpretation of the term "financial statements" was not changed in the Glossary. } \\
\text { 5. The term "other historical financial information" is found in three International Standards } \\
\text { only when indicating the possibility of adapting the International Standards on Auditing } \\
\text { (ISA 200, ISA 260, and ISA 805). } \\
\text { 6. International Standards on Auditing and International Standards of Engagements for Review } \\
\text { continue to use the term "financial statements", although the blocks themselves are called } \\
\text { "Audits of Historical Financial Information" and "Reviews of Historical Financial Information". } \\
\text { 7. The term "historical financial information" is used broadly in the reviewed standards. }\end{array}$ \\
\hline
\end{tabular}

So the term "historical financial information" was firstly suggested only in the International Standards of 2010 and it has not been changed in further editions. The Glossary of Terms states that "historical financial information is the information expressed in financial terms in relation to a particular entity, derived primarily from that entity's accounting system, about economic events occurring in past time periods or about economic conditions or circumstances at points in time in the past." The term "financial statements" is interpreted as 
a "structured representation of the historical financial information, which ordinarily includes accompanying notes, derived from accounting records and intended to communicate an entity's economic resources or obligations at a point in time or the changes therein for a period of time in accordance with a financial reporting framework." The term can refer to a complete set of financial statements, but it can also refer to a single financial statement, for example, a balance sheet, or a statement of revenues and expenses, and related explanatory notes. These definitions remain unchanged in further editions of International Standards.

At the same time, International Standards do not indicate that financial statements are just one form of structured representation of historical financial information. The term "other historical financial information" is found in International Standards only when indicating that the ISA is set out in the context of the audit of the financial statements and should be adapted, as appropriate, when using other historical financial information during the audit. This remark is in the Preface to the International Quality Control, Auditing, Review, Other Assurance, and Related Services Pronouncements (Paragraph 11), ISA 200 "Overall Objectives of the Independent Auditor and the Conduct of an Audit in Accordance with International Standards on Auditing" (Paragraph 2), ISA 260 "Communication with those Charged with Governance" (Paragraph 2), ISA 805 "Special Consideration - Audits of Single Financial Statements and Specific Elements, Accounts or Items of a Financial Statement" (Paragraph 1). Only in the Application and other Explanatory Material of ISA 805 "Other Historical Financial Information" is associated with single financial statements and specific elements, accounts or items of a financial statement. In Appendix 1, examples of such other historical financial information (specific elements, accounts or items of a financial statement) are listed:

- Accounts receivable, allowance for doubtful accounts receivable, inventory, the liability for accrued benefits of a private pension plan, the recorded value of identified intangible assets, or the liability for "incurred but not reported" claims in an insurance portfolio, including related notes;

- A schedule of externally managed assets and income of a private pension plan, including related notes;

- A schedule of net tangible assets, including related notes;

- A schedule of disbursements in relation to a lease property, including explanatory notes;

- A schedule of profit participation or employee bonuses, including explanatory notes.

Therefore, the term "historical financial information" has a broader meaning than the term "financial statements" and contains other information but only that can be obtained from the accounting information system. In fact, taking into account the content of the abovementioned definitions, we can conclude that historical financial information can be expressed in various structured forms, not only in the form of financial statements, as this is not mentioned in the definition. For example, tax reports are also information expressed in financial indicators that are obtained primarily using the company accounting system.

This issue requires a clearer solution. In some countries, where value and relevance of other types of reporting, in particular tax, statistical and managerial are extremely high (this applies to Ukraine), it is difficult to determine which type of engagements (audit or other assurance engagements) should be used in such cases.

\section{Substantiation of two approaches to the definition of the term "historical financial information" as the main criterion for the differentiation of audit, review, and other assurance engagements}

In the present situation, two solutions are possible. On the one hand, traditionally, the terms "historical financial information" and "financial statements" as a form of its structured representation are linked. And if to follow literally the terms of International Standards, it is possible to limit the term "historical financial information" to only:

(1) Full set of financial statements (all ISA);

(2) Financial statements prepared in accordance with the special purpose framework (ISA 800 "Special Consideration-Audits of Financial Statements Prepared in Accordance with Special Purpose Framework");

(3) Single financial statements, specific elements, accounts or items of a financial statement (ISA 805 "Special Consideration - Audits of Single Financial Statements and Specific Elements, Accounts or Items of a Financial Statement");

(4) Summaryfinancial statements (ISA810 "Engagements to Report on Summary Financial Statements").

However, the term "historical financial information" may be considered broader with the following required elements:

(1) Information should be expressed in financial terms in relation to a particular entity;

(2) Information should disclose economic events occurring in past time periods or about economic conditions or circumstances at the points of time in the past;

(3) Information should be derived primarily from that entity's accounting system.

By this approach, the types of historical financial information are broadened.

The use of a broad approach to the interpretation of the term "historical financial information" allows, firstly, specifying the objects of the engagements, and secondly, expanding the understanding of the structured representation of historical financial information and the nature of the audit engagements. 
If we adopt a broad approach to the interpretation of the term "historical financial statements", then examples of its types can be:

I. Full set of financial statements, its components, articles, items or accounts as components of financial statements (traditional presentation).

II. Other forms of reports:

(1) Tax reports, its individual components, articles, and items;

(2) Statistical reports, its components, articles, and elements;

(3) Internal (managerial) reports, its components, articles, and elements (but only that which corresponds to the abovementioned required elements).

III. Various official financial and accounting records that contain historical financial information, such as statements of receivable balances and current liabilities (but only that which corresponds to the abovementioned required elements).

The problem of application of this approach is that the ISAs are only aimed at disclosing the audit issues, it is the financial statements that are specifically mentioned in ISA: ISAs are written in the context of the audit of financial statements (ISA 200 (Paragraph 2), ISA 805 (Application and Other Materials A3). The requirements of ISA are sufficiently sound; they have established the obligatory study of specific objects, in particular, the system of internal control, observance of the principle of continuity, subsequent events, etc. The study of the issues mentioned above may not be obligatory in terms of user requirements, for example, when the subject matter is statistical or tax reports. Noting that this is an audit engagement performed under the ISA, the auditor immediately sets requirements for organizing it, for example, considering the applicability of ISA 570 'Going Concern" and other specific standards. ISA 200 and ISA 805 allow adapting International Standards on Auditing in the circumstances if they are applied to the audit of "other historical financial information" but require an analysis of the appropriateness and necessity of applying certain ISAs.

In the context of considering this problem, it should be noted that in recent years, analytical studies have been published on the conditions of application and the benefits of such types of tasks that are subject to the IAASB International Standards, such as reviews of historical financial information and related services, especially Engagements to Perform Agreedupon Procedures Regarding Financial Information (International Standard for Related Services (ISRS) 4400). In particular, the Federation of European Accountants has been offered Survey on the Provision of Alternative Assurance and Related Services across Europe, which analyses the differences between different services. Their execution is appropriate in cases where users require a limited level of assurance or only results of comparisons of the data of the primary documents and generalized accounting information.
If we assume that historical financial information has a broad interpretation, then it is possible to conclude that audit as an assurance engagement can also be performed in two forms:

(1) Direct Engagements;

(2) Attestation Engagements.

These types of assurance engagements are considered in the International Framework for Assurance Engagements, but they are only considered in detail in relation to other assurance engagements, that is, assurance engagements other than audit or review of historical financial information.

The second type of the engagement is a traditional audit of financial statements, in which the subject of the engagement (information about the financial position, performance, and cash flows) and subject matter information (financial statements) are clearly regulated and prepared by the responsible party.

But the first type of engagement is an engagement that can be performed without a structured presentation of subject matter information that covers historical financial information. In a direct engagement, the auditor measures or evaluates the underlying subject matter against the criteria. In addition, the practitioner applies assurance skills and techniques in order to obtain adequate evidence of the outcome of the measurement or evaluation of the underlying subject against these criteria. Information on the subject of the engagement is provided to users in the report. The need for such an engagement may arise in the absence of certain information in the financial statements. For example, it may be necessary to perform the engagement of auditing cash flow in foreign currency as direct engagements, since the cash flow statement provides generalized information and there is no detailed information about the type of currency.

\section{Application of a broad approach to specifying the type of assurance engagement}

If we adopt a broad approach, then it is possible to identify the entities that will serve as a subject for various assurance engagements: the audit engagements that will be performed in accordance with the ISA, or other assurance engagements that will be performed in accordance with the International Standard on Assurance Engagement 3000 "Assurance Engagements Other than Audits or Reviews of Historical Financial Information". The approach is based on the analysis of a compliance with the mandatory elements of the definition of the term "historical financial information".

This analysis is useful when the subject of the engagement is not reporting as a whole, but individual entities.

Figure 1 shows the relationship between the characteristics of the subject, information on the subject of the problem and types of engagement, which can be used to develop an algorithm for identifying the type of engagement. 


\begin{tabular}{|c|c|c|c|}
\hline \multicolumn{4}{|c|}{$\begin{array}{c}\text { The sequence of the study of subject and information on the subject of engagement to select the } \\
\text { type of engagement }\end{array}$} \\
\hline 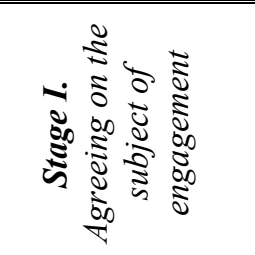 & $\begin{array}{l}\text { Settlements with buyers } \\
\text { and customers and their } \\
\text { presentation in accounting } \\
\text { and financial reporting }\end{array}$ & $\begin{array}{l}\text { Settlements with buyers } \\
\text { and customers and their } \\
\text { presentation in accounting } \\
\text { and financial reporting }\end{array}$ & $\begin{array}{l}\text { Forecasting of cash flow } \\
\text { from buyers and customers }\end{array}$ \\
\hline 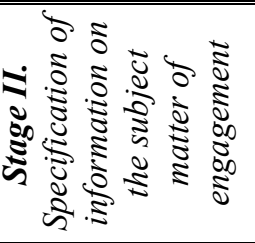 & $\begin{array}{c}\text { Balance Sheet Articles, } \\
\text { Statement of Financial } \\
\text { Results, Statement of } \\
\text { Cash Flows, Notes }\end{array}$ & $\begin{array}{l}\text { Agreements, documents } \\
\text { on payment, shipment, } \\
\text { documents for settling } \\
\text { claims, litigation }\end{array}$ & $\begin{array}{l}\text { Financial forecasts of } \\
\text { cash flows from buyers } \\
\text { and customers }\end{array}$ \\
\hline \multirow{3}{*}{ 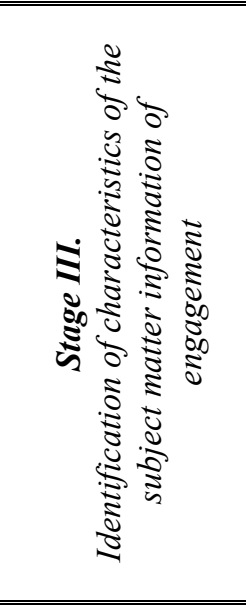 } & $\begin{array}{c}\text { Information about } \\
\text { calculations is expressed } \\
\text { in financial indicators }\end{array}$ & $\begin{array}{l}\text { Information on the } \\
\text { subject is expressed in } \\
\text { financial terms but } \\
\text { mainly in descriptive } \\
\text { terms }\end{array}$ & $\begin{array}{c}\text { Financial forecasts are } \\
\text { presented in financial } \\
\text { indicators }\end{array}$ \\
\hline & $\begin{array}{l}\text { Information reveals the } \\
\text { results and volume of } \\
\text { settlements with buyers } \\
\text { and customers that took } \\
\text { place in the past }\end{array}$ & $\begin{array}{l}\text { The assessments are also } \\
\text { subject to documents } \\
\text { drawn up in the past, and } \\
\text { organizational and } \\
\text { administrative documents }\end{array}$ & $\begin{array}{l}\text { Information discloses } \\
\text { forecast of financial } \\
\text { information }\end{array}$ \\
\hline & $\begin{array}{l}\text { Information is obtained } \\
\text { from the accounting } \\
\text { system }\end{array}$ & $\begin{array}{l}\text { Information at the same } \\
\text { time is derived from the } \\
\text { accounting system and is } \\
\text { the basis for it }\end{array}$ & $\begin{array}{l}\text { Forecast calculations are } \\
\text { performed on the basis of } \\
\text { historical information } \\
\text { obtained from the } \\
\text { accounting system }\end{array}$ \\
\hline \multirow{6}{*}{ 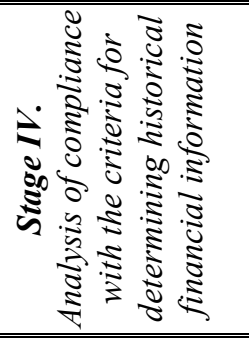 } & \multicolumn{3}{|c|}{ Is information expressed in financial terms in relation to a particular entity? } \\
\hline & + & - & + \\
\hline & \multicolumn{3}{|c|}{$\begin{array}{l}\text { Does information disclose economic events occurring in past time periods or about } \\
\text { economic conditions or circumstances at points in time in the past? }\end{array}$} \\
\hline & + & $-/+$ & - \\
\hline & \multicolumn{3}{|c|}{ Is information derived primarily from that entity's accounting system? } \\
\hline & + & $-/+$ & $-/+$ \\
\hline 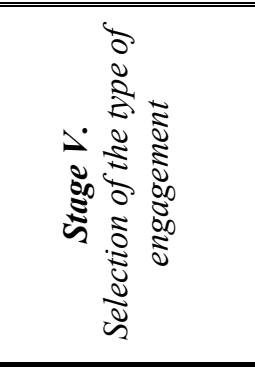 & $\begin{array}{l}\text { Audit Engagement of } \\
\text { displaying the results of } \\
\text { settlements with buyers } \\
\text { and customers in the } \\
\text { financial statements, } \\
\text { which will be executed in } \\
\text { accordance with the ISA, } \\
\text { taking into account the } \\
\text { requirements of ISA } 805\end{array}$ & $\begin{array}{l}\text { Assurance Engagement } \\
\text { other than Audit or } \\
\text { Review of Historical } \\
\text { Financial Information, } \\
\text { which will be executed in } \\
\text { accordance with ISAE } \\
3000\end{array}$ & $\begin{array}{l}\text { Assurance Engagement } \\
\text { other than Audit or } \\
\text { Review of Historical } \\
\text { Financial Information, } \\
\text { which will be executed in } \\
\text { accordance with the ISAE } \\
3400\end{array}$ \\
\hline
\end{tabular}

Figure 1. Study of the subject matter and subject matter information using a broad approach as the basis of the algorithm for identifying the type of assurance engagement 
Table 2

Display of the influence of approaches concerning the interpretation of the term "historical financial information"

\begin{tabular}{|c|c|c|}
\hline Criteria & Narrow approach & Broad approach \\
\hline Essence & $\begin{array}{l}\text { To limit the term "historical financial information" } \\
\text { to information that is presented in a complete set of } \\
\text { financial statements, a separate financial statement, an } \\
\text { account, an article or item of financial statements. }\end{array}$ & $\begin{array}{l}\text { To consider the term "historical financial information" } \\
\text { taking into account its key elements without reference } \\
\text { to financial statements. }\end{array}$ \\
\hline Advantages & $\begin{array}{l}\text { - clarity, lack of ambiguity in the interpretation, } \\
\text { preservation of the traditional approach to audit review }\end{array}$ & $\begin{array}{l}\text { - widening of the range of objects in accordance with } \\
\text { the requirements of International Standards }\end{array}$ \\
\hline Disadvantages & $\begin{array}{l}\text { Outside of the sphere of influence, there is other } \\
\text { historical financial information that falls neither under } \\
\text { the scope of the influence of ISA nor under the sphere } \\
\text { of influence of the ISAE. }\end{array}$ & $\begin{array}{l}\text { Lack of clear recommendations for the adaptation of } \\
\text { provisions of International Standards on Auditing when } \\
\text { verifying other historical financial information. }\end{array}$ \\
\hline \multirow{3}{*}{$\begin{array}{l}\text { Impact on International } \\
\text { Standards and Expected } \\
\text { Changes }\end{array}$} & \multicolumn{2}{|c|}{$\begin{array}{l}\text { To specify the term "other historical financial information" and the possible forms } \\
\text { of its structured representation. }\end{array}$} \\
\hline & $\begin{array}{l}\text { To provide the scope of the International Standards on } \\
\text { Auditing only for the audit of financial statements. }\end{array}$ & $\begin{array}{l}\text { To provide clearer conditions for the adaptation of } \\
\text { provisions of International Standards on Auditing } \\
\text { when verifying other historical financial information, } \\
\text { in particular, tax, statistical and other reporting forms, } \\
\text { financial and accounting documents. }\end{array}$ \\
\hline & $\begin{array}{l}\text { To introduce certain International Standards on } \\
\text { Assurance Engagements of other historical financial } \\
\text { information and possible forms of its structured } \\
\text { representation. }\end{array}$ & $\begin{array}{l}\text { To extend the provisions of the International Standards } \\
\text { on Auditing in order to regulate the requirements for } \\
\text { carrying out audit engagements of other historical } \\
\text { financial information as a direct engagement. }\end{array}$ \\
\hline $\begin{array}{l}\text { Development trends } \\
\text { in the national systems } \\
\text { of statutory regulation } \\
\text { of audit activity }\end{array}$ & $\begin{array}{l}\text { To develop Provisions on National Practices on } \\
\text { Assurance Engagements of other historical financial } \\
\text { information and possible forms of its structured } \\
\text { representation (for example, tax reports). }\end{array}$ & $\begin{array}{l}\text { To develop the National Practice on Audit of Other } \\
\text { Historical Financial Information as an Attestation } \\
\text { Engagement. } \\
\text { To develop the National Practice on Audit of Other } \\
\text { Historical Financial Information as a Direct Engagement. }\end{array}$ \\
\hline
\end{tabular}

\section{Comparison of two approaches to the definition of "historical financial information" in developing directions for the development of standards and regulatory assurance engagements}

Table 2 presents the systematization of problems of the influence of "narrow" and "broad" approaches to the interpretation of the essence of the term "historical financial information" of the content and directions for the improvement of International Standards and national regulatory documents.

\section{Conclusions}

For further development of the theory and practice of performing assurance engagements, it is important to clearly distinguish the audit and review of historical financial information from other assurance engagements. The main criterion for their selection is the subject of the engagement "historical financial information" and, accordingly, the possible forms of its structured representation. To do this, it is necessary to specify the content of the term "historical financial information" in the context of its application in the International Standards. It is substantiated that two historical approaches to the interpretation of the term "historical financial information" can be applied: the narrow approach is used when the term "historical financial information" is limited to a complete set of financial statements, a separate financial statement, an account, an article or item of financial statements, and the broad approach that involves the use of mandatory characteristics of historical financial information as the basis for the allocation of its various groups, forms of structured representation and the algorithm for selecting objects that may be subject to various assurance engagements. The selected advantages and disadvantages of each approach determine further development of standards in the sphere of performing audit services and statutory regulation at the level of international standards and regulations (standards) at the national level.

\section{References:}

Arens A.A. \& Loebbecke J. (1995). Auditing: An Integrated Approach. Ya.V. Sokolov (Ed.). Moscow: Finance and Statistics. (in Russian)

Artyukh O.V. (2015) Podatkovyy audyt yak zavdannya z nadannya dostatnoyi vpevnenosti [Tax audit as a reasonable assurance engagement]. Naukovyy visnyk Mizhnarodnoho humanitarnoho universytetu. Seriya: Ekonomika ta menedzhment. - Scientific Bulletin of the International Humanitarian University. Series: Economics and Management, 12, 235-238. (in Ukrainian) 
Australian Government. Department of Finance (2014). Resource Management Guide No. 210 Clarification of the terms 'Audit' and 'Assurance'. November, 2014. www.finance.gov.au Retrieved from: http://www.finance.gov.au/ sites/default/files/RMG-210-Clarification-of-the-terms-Audit-and-Assurance.pdf

Davydov H.M., Davydov I.H., Davydov Yu.H., Nazarova H.B., Pugachenko O.B., Fomina T.V. \& et al (2009). Audyt: pidruchnyk [Audit: textbook]. H.M. Davydov \& M.V. Kuzelnyi (Ed.). Kyiv: Znannia. (in Ukrainian)

Drd. Pop (Grigorescu) I.L. (2012). The Evolution and the Perspectives of the Audit. International Journal of Academic Research in Business and Social Sciences, Vol. 2, No. 4, 264-280.

Eilifsen A., Messier Jr., W.F., Glover S. \& Prawitt D. (2006). Auditing and Assurance Services, McGraw-Hill Education, Maidenhead, UK.

Fédération des Experts comptables Européens - Federation of European Accountants (FEE) (2009). Survey on the Provision of Alternative Assurance and Related Services Across Europe. July 2009. Retrieved from: http://www.fee.be/ images/publications/auditing/Assurance_Survey_color2472009251643.pdf

Gill G., Cosserat G., Leung P. \& Coram P. (2001). Modern Auditing and Assurance Services, John Wiley \& Sons Australia Ltd, Milton, Australia.

Hasan M., Maijoor S., Mock T.J., Roebuck P., Simnett R. \& Vanstraelen A. (2005). The Different Types of Assurance Services and Levels of Assurance Provided. International Journal of Auditing, 9, 91-102.

Hedz M.I. (2007). Klasyfikatsiia audytu za obiektamy [Classification of Audit by Objects]. Menedzhment ta pidpryiemnytstvo $v$ Ukraini: etapy stanovlennia i problemy rozvytku. Visnyk Natsionalnoho universytetu $\ll$ Lvivska politekhnika $\gg-$ Management and entrepreneurship in Ukraine: stages of formation and development problems. Bulletin of the Lviv Polytechnic National University, 577, 76-81. (in Ukrainian)

Higson A. (2014). Corporate Financial Reporting. Theory and Practice. Sage Publishing.

International Federation of Accountants (IFAC/IAASB) (2003). Handbook of International Auditing, Assurance, and Ethic Pronouncement. 2003 Edition. Retrieved from: www.mas-business.com/docs/2005_IAASB_HandBook.pdf

International Federation of Accountants (IFAC/IAASB) (2004). Handbook of International Auditing, Assurance, and Ethic Pronouncement. 2004 Edition. Retrieved from: www1.worldbank.org/publicsector/pe/.../IAASB Auditing\%20Handbook_2004.pdf

International Federation of Accountants (IFAC/IAASB) (2005). Handbook of International Auditing, Assurance, and Ethic Pronouncement. 2005 Edition. Retrieved from: www.mas-business.com/docs/2005_IAASB_HandBook.pdf

International Federation of Accountants (IFAC/IAASB) (2010). Handbook of International Quality Control, Auditing, Review, Other Assurance, and Related Services Pronouncements, Part I, 2010 Edition. Retrieved from: https:/9www.ifac.org/publications-resources/2010-handbook-international-quality-control-auditing-review-other International Federation of Accountants (IFAC/IAASB) (2010). Handbook of International Quality Control, Auditing, Review, Other Assurance, and Related Services Pronouncements, Part II, 2010 Edition. Retrieved from: https:/\%www.ifac.org/publications-resources/2010-handbook-international-quality-control-auditing-review-other International Federation of Accountants (IFAC/IAASB) (2012). Handbook of International Quality Control, Auditing, Review, Other Assurance, and Related Services Pronouncements, Volume I, 2012 Edition. Retrieved from: https:/9www.ifac.org/publications-resources/2012-handbook-international-quality-control-auditing-review-other International Federation of Accountants (IFAC/IAASB) (2012). Handbook of International Quality Control, Auditing, Review, Other Assurance, and Related Services Pronouncements, Volume II, 2012 Edition. Retrieved from: https:/\%www.ifac.org/publications-resources/2012-handbook-international-quality-control-auditing-review-other International Federation of Accountants (IFAC/IAASB) (2013). Handbook of International Quality Control, Auditing, Review, Other Assurance, and Related Services Pronouncements, Volume I, 2013 Edition. Retrieved from: https:/\%www.ifac.org/publications-resources/2013-handbook-international-quality-control-auditing-review-other International Federation of Accountants (IFAC/IAASB) (2013). Handbook of International Quality Control, Auditing, Review, Other Assurance, and Related Services Pronouncements, Volume II, 2013 Edition. Retrieved from: https:/\%www.ifac.org/publications-resources/2013-handbook-international-quality-control-auditing-review-other International Federation of Accountants (IFAC/IAASB) (2014). Handbook of International Quality Control, Auditing, Review, Other Assurance, and Related Services Pronouncements, Volume I, 2014 Edition. Retrieved from: https:/\%ww.ifac.org/publications-resources/2014-handbook-international-quality-control-auditing-review-other International Federation of Accountants (IFAC/IAASB) (2014). Handbook of International Quality Control, Auditing, Review, Other Assurance, and Related Services Pronouncements, Volume II, 2014 Edition. Retrieved from: https:/\%ww.ifac.org/publications-resources/2014-handbook-international-quality-control-auditing-review-other International Federation of Accountants (IFAC/IAASB) (2014). Supplement to the Handbook of International Quality Control, Auditing, Review, Other Assurance, and Related Services Pronouncements, Volume III, 2014 Edition. Retrieved from: https://www.ifac.org/publications-resources/2014-handbook-international-quality-controlauditing-review-other

International Federation of Accountants (IFAC/IAASB) (2015). Handbook of International Quality Control, Auditing, Review, Other Assurance, and Related Services Pronouncements, Volume I, 2015 Edition. Retrieved from: https:/9www.ifac.org/publications-resources/2015-handbook-international-quality-control-auditing-review-other International Federation of Accountants (IFAC/IAASB) (2015). Handbook of International Quality Control, Auditing, Review, Other Assurance, and Related Services Pronouncements, Volume II, 2015 Edition. Retrieved from: https:/9www.ifac.org/publications-resources/2015-handbook-international-quality-control-auditing-review-other 
International Federation of Accountants (IFAC/IAASB) (2015). Supplement to the Handbook of International Quality Control, Auditing, Review, Other Assurance, and Related Services Pronouncements, Volume III, 2015 Edition. Retrieved from: https://www.ifac.org/publications-resources/2015-handbook-international-quality-controlauditing-review-other

International Federation of Accountants (IFAC/IAASB) (2016-2017). Handbook of International Quality Control, Auditing, Review, Other Assurance, and Related Services Pronouncements, Volume I, 2016-2017 Edition. Retrieved from: https://www.ifac.org/publications-resources/2016-2017-handbook-international-quality-control-auditingreview-other

International Federation of Accountants (IFAC/IAASB) (2016-2017). Handbook of International Quality Control, Auditing, Review, Other Assurance, and Related Services Pronouncements, Volume II, 2016-2017 Edition. Retrieved from: https://www.ifac.org/publications-resources/2016-2017-handbook-international-quality-control-auditingreview-other

International Federation of Accountants (IFAC/IAASB) (2016-2017). Supplement to the Handbook of International Quality Control, Auditing, Review, Other Assurance, and Related Services Pronouncements, Volume III, 2016-2017 Edition. Retrieved from: https://www.ifac.org/publications-resources/2016-2017-handbook-internationalquality-control-auditing-review-other

Ittonen K. (2010). A Theoretical Examination of the Role of Auditing and the Relevance of Audit Reports. VAASA.

Janković S. \& Krivačić D. (2014). he Assurance of Sustainability Reporting of Hotel Companies. Tourism and Hospitality Industry 2014. Congress Proceedings. Trends in Tourism and Hospitality Industry, 51-69. Retrieved from: http://www.fthm.uniri.hr/files/Kongresi/THI/Papers/2014/THI_May2014_51to69.pdf

Malyshkin O.I. (2015). Audyt podatkiv: konstruktsiya na maybutnye [Audit of taxes: design for the future]. Ekonomika: realiyi chasu - Economy: realities of time, 1(17): 208-213. Retrieved from: http://economics.opu.ua/ files/archive/ 2015/No1/208-213.pdf (in Ukrainian)

Mezhdunarodnyye standarty audita i Kodeks etiki professionalnykh bukhgalterov. [International Standards on Auditing \& IFAC of Ethics. 1999] (2000). Moscow. (in Russian)

MFB 2001. Standarty audytu ta etyky. [IFAC 2001. Standards for auditing and Ethics] (2003). Kyiv: Parytet-inform. (in Russian)

O'Reilly V.M., Hirsh M.B., DeFliese Ph.L. \& Jaenicke H.R. (1997). Montgomery's Auditing, 11th Ed., trans. Ya.V. Sokolov \& S.M. Bychkova. Moscow: Audit, UNITY. (in Russian)

Pankova S.V. (2013). O ponyatii «uverennost» v auditorskoy deyatelnosti i klassifikatsii auditorskikh uslug [On the notion of "confidence" in auditing and the classification of audit services]. Mezhdunarodnyy bukhgalterskiy uchet - International accounting, 34(280), 27-33. (in Russian)

Petryk O.A., Davydov H.M., Redko O.Yu., Shevchuk V.O., Zotov V.O., Sviderskyi D.E. \& et al (2012). Audyt opodatkuvannya pidpryyemstv : navchalnyy posibnyk / [Audit of taxation of enterprises: textbook]. O.A. Petryk (Ed.). Kyiv: «Akademia finansovoho upravlinnya». (in Ukrainian)

Proskurina N.M. (2014) Audyt dotrymannya pryntsypu bezperervnosti yak perspektyvnyy napryamok rozvytku audytu [Audit of compliance with the principle of continuity as a perspective direction of audit development]. Visnyk Lvivskoyi komertsiynoyi akademiyi. Seriya : Ekonomichna. - Visnyk of the Lviv Commercial Academy. Series: Economical, 44, 144-147. (in Ukrainian)

Samchynska Ya.B. (2012). Informatsiyno-normatyvne zabezpechennya suputnikh posluh $\mathrm{z}$ vykonannya pohodzhenykh protsedur [Information and regulatory support of related services for the implementation of agreed procedures]. Visnyk Khmelnytskoho natsionalnoho universytetu - Bulletin of the Khmelnitsky National University, 2, 1, 96-99. (in Ukrainian)

Simnett R., Nugent M. \& Huggins A. L. (2009). Developing an International Assurance Standard on Greenhouse Gas Statements. Accounting Horizons. American Accounting Association, Vol. 23, No. 4, 347-363. Retrieved from: http://dx.doi.org/10.2308/acch.2009.23.4.347

Soltani B. (2007). Auditing: An International Approach. Financial Times Press.

Sonnerfeldt A. (2014). Regulating third party assurance engagements on sustainability reports in Sweden - issues and challenges. European Company Law, Volume 11 (2014) Issue 2; University of Oslo Faculty of Law Research Paper No. 2014-30. Retrieved from: http://dx.doi.org/10.2139/ssrn.2471522 